TEME, г. XLIII, бр. 2, април - јун 2019, стр. 657-659

\author{
Приказ дела \\ Примљено: 21. 12. 2018. \\ https://doi.org/10.22190/TEME181221040J \\ Одобрено за штампу: 21. 6. 2019.
}

\title{
ЖАРГОН И ЈУЖНА ПРУГА *
}

\author{
Александра А. Јанић \\ Универзитет у Нишу, Филозофски факултет, Ниш, Србија \\ aleksandra.janic@filfak.ni.ac.rs
}

Крајем 2018. године у издању Филозофског факултета у Нишу објављен је Речник жаргонизама јужне пруге аутора̂ Јордане Марковић и Татјане Трајковић. Ради се о грађи из југоисточне Србије, а употребивши синтагму јужна пруга, аутори су постигли следеће: 1) избегли су прецизно географско дефинисање граница, што је био примарни циљ; 2) у самом наслову овог речника жаргонизама употребили су жаргонизам, што је секундарно, али доприноси језгровитости наслова и има стилски ефекат.

Информатори за Речник жаргонизама јужне пруге били су, како аутори наводе, ученици, студенти, млади, али и особе средњег и старијег узраста из југоисточне Србије. Из тог разлога, грађа је разноврсна: има дијалекатске лексике, жаргонизама карактеристичних и за друге крајеве Србије, као и лексема из стандардног српског језика које су добиле жаргонско значење, те англицизама.

Број лексикографских одредница није наглашен у Уводним напоменама овог речника, али увидом у одреднице долазимо до закључка да их има скоро 3000, што је у просеку 14 одредница по страни. Понекад чак није лако повући границу између жаргонизма и дијалектизма, те жаргонизма и стандардне речи, јер зависи од тога да ли то процењује старији или млађи говорник и из ког је краја говорник.

У речнику смо приметили следећа семантичка поља: школску лексику, компјутерску лексику, именовање особа са конкретним особинама, занимања, именовање простора, предмета и сл. За сваку наведену групу навешћемо по неколико примера, уз значења и евентуалне специфичности. Након тога, издвојићемо и прокоментарисаћемо примере жаргонских придева и глагола, шатровачке речи, те лексеме дијалекатског порекла и оне које воде порекло из енглеског језика.

У оквиру школске лексике, издвојили смо следеће одреднице: адвокатура „уставно право као предмет”, алхемија „хемија”, архива „књига, свеска”, двица „двојка као оцена”, дебилана „школа”, директор „председник одељењске заједнице”, домаћински „српски језик”, енглескињ $а$ „професорка

\footnotetext{
* Јордана Марковић, Татјана Трајковић, Речник жаргонизама јужне пруге, Филозофски факултет у Нишу, Ниш, 2018, 217 стр.
} 
енглеског”, кречење „ликовно образовање”, мртвак „латински језик”. Превасходно се тичу предмета, предавача и боравка ученика у школи.

Компјутерска лексика честа је у свакодневном говору, те су у Речнику жаргонизама јужне пруге своје место нашле и лексеме попут виралеш „бежични интернет”, инста „друштвена мрежа инстаграм” и комп „компјутер”.

Именовање човека према карактеристичној особини коју поседује семантичко је поље које садржи пуно жаргонских лексема. Издвајамо следеће: ајкула „способна и агресивна особа”, вампир „особа која води ноћни живот”, гииа „дебела женска особа”, даска „веома мршава девојка”, дизелаш „особа која прати трендове деведесетих (у моди)”, дрво „много пијана особа”, зујалица „1. особа која стално прича. 2. особа која стално негде жури”, језичара „женска особа која пуно прича”, камен „глупа особа”, канщер „досадна особа". Поједине од наведених лексема припадају стандарду, али им је новодобијено значење жаргонско (на пример, вампир, камен, канцер).

Међу лексемама којима се именују занимања, налазе се лексеме гиша „гинеколог”, гуштер „регрут, млад војник”, жардињерија „комунална полиција”, кер „полицајац”, пандуращија „полиција”, психић „психијатар”, при чему су видљиви метафорички преноси (попут лексеме гуштер) и творбени процеси (пандуращија, психић и сл.).

Лексеме и изрази са значењем простора су оне попут: азил „место боравка”, весели центар „тоалет”, жута зграда „лудница”, клаца „кладионица, спортска кладионица”, книнца „кинеска продавница”, мувалиште „кафић”, мучионица „учионица”, проца „продавница”.

Именовање предмета из свакодневног живота илуструјемо следећим жаргонским лексемама: вајферт „новчаница хиљадарка”, камење „накит”, колица „аутомобил”, контејнер „велики и неисправан аутомобил”, лоне „панталоне”, скакавац „нож”, фотка „фотографија”.

У именовању делова људског тела жаргонизмима чести су метафорички преноси, и то најчешће према сличности по облику, боји, величини и функцији. Издвајамо следеће жаргонизме који се односе на делове људског тела: домине „зуби”, кесе „подочњаци”, кифлице „сало на стомаку”, крем бананице „дебеле обрве”, лопата „велика шака”, лопате „велики зуби”, морске пијавице „густе обрве”, њокалица „нос”, офингер „велики нос”, пропеле$p u$ „велике уши”. Међу њима има синонимичних или блискозначних: домине и лопате; крем бананице и морске пијавице. Са друге стране, граматички број може утицати на жаргонско значење (уп. лопата и лопате).

Од жаргонских придева издвајамо: зебраст, - $a$, -о „који је сумњив”, криминалан, -лна, -лно „који је интересантан, духовит, интелигентан, забаван”, кутлав, - $a$, -о „који је са кривим ногама”, нафуран, - $a$, -о „који је уображен умишљен”, њољав, - $a$, -о „који има велики нос”, проваљен, - $a$, -о „који је разоткривен".

Међу жаргонским глаголима су они попут леши „туче, пребија”, лунза$p a$ „шета бесциљно”, мрљави ,једе споро и без апетита”, набаиује се „удвара се, намеће се”, накачиње се „непожељно се убацује у друштво”, наирта се „дође”, обања се „окупа се”, опасуљи се „дође к себи, опамети се”, почапа се „посвађа се, потуче се”, ринта „тешко ради”. Због природе подручја, глаголи су у овом речнику навођени у облику 3 . лица једнине презента.

Шатровачке речи такође су део овог речника жаргонизама, али не све, будући да је на „шатровачки начин”, односно са извршеном метатезом, 
могуће изговорити сваку вишесложну реч. Уврштени су примери таквих устаљених лексема, попут вопи „пиво”, вугла „глава”, воздра „здраво”, љаксе „сељак”.

Међу до сада наведеним лексемама много је оних који са другачијим значењем постоје у стандардном српском језику (кесе, крем бананице, пропелери, кифлице, домине и сл., с тим што су неке у жаргону pluralia tantum), a осим већ наведених дијалекатских (поцапа се, опасуљи се, леши, њоњав и сл.), издвајамо још неке чисто дијалекатски маркиране лексеме: $\partial p ч љ a$ „халапљива особа”, зврндов „несташко”, рчка „претура”, рунза „плаче”, штукне „нестане”.

Англицизми су саставни део жаргона српског језика, што потврђује лексема даун (израз бити у дауну „бити у лошем расположењу”) и друге лексеме преузете са енглеским изговором, на пример, јуро „евро”, мајк „микрофон”, рилекс „опусти се”, тату „тетоважа”, фејк „лажан”, фриц „фрижидер”.

Занимљива појава коју смо приметили јесте да су се међу жаргонизмима јавили не само синонимни парови већ и синонимски низови. Један такав пример синонимског низа односи се на значење пијане особе: бадњак, дрво, летва, кифла, метак, патос итд. Са друге стране, јављају се и случајеви творбено међусобно повезаних примера са другачијим, неповезаним жаргонским значењем: камен „глупа особа” и камење „огрлица”. Лексеме себић и својко у значењу „селфи” подсећају нас на потенцијалне речи или оказионализме, а не на оне које су уобичајене у употреби. Креативност у творби жаргонизама посебно је видљива у примеру њамбургер „хамбургер”, где су сливене речи њам и хамбургер, што Ранко Бугарски у књизи Жаргон назива лексичком скривалицом.

Након свега наведеног, намеће се закључак да се значај Речника жаргонизама јужне пруге посебно огледа у новим примерима жаргонизама, и то са дијалекатског подручја југоисточне Србије и урбаног подручја Ниша и околних градова. Након Београдског фрајерског речника Петрита Имамија и монографије Музички жаргон младих и музыкальный молодёжный Софије Милорадовић, Речник жаргонизама јужне пруге је подстицај за осмишљавање нових речника жаргона из осталих дијалекатских подручја Србије, те би се на тај начин могле анализирати сличности и разлике међу жаргонизмима употребљаваним у различитим крајевима Србије. 